\title{
Goals and benefits of digital transformation projects: Insights into project selection criteria
}

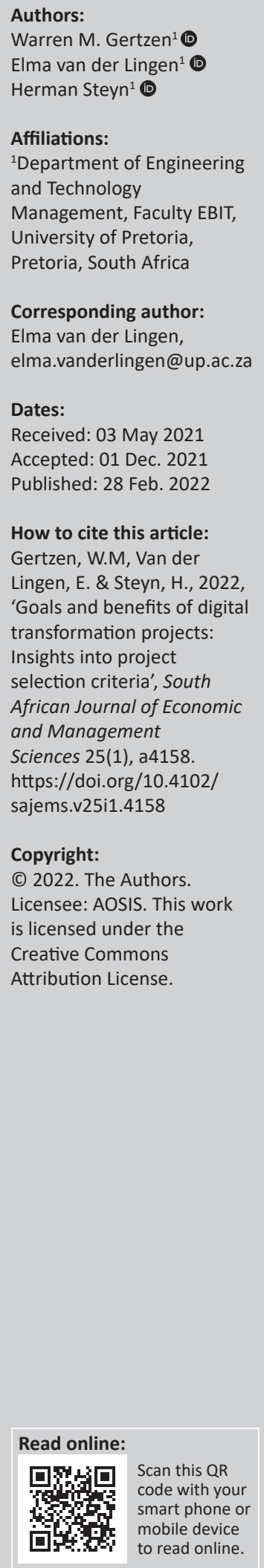

Background: Digital transformation (DT) is an increasingly relevant concept for businesses to remain competitive. As DT projects are disruptive to an organisation and are significantly different from traditional information technology projects, it is important to understand the value that specific DT projects will bring to an organisation before they are implemented, so that DT project portfolios can be optimally managed.

Aim: This study aims to determine the key goals and benefits of DT projects, as well as the selection criteria for DT projects in South African businesses. The study also explores the most influential technologies for driving the implementation of DT projects.

Setting: South Africa is an emerging economy. The study was performed in the initial phases of nationwide lockdown owing to COVID-19.

Methods: Semi-structured interviews were conducted with 11 leaders from South African businesses of varying sizes, but all in significant local markets. Content analysis using CAQDAS was used to analyse the primary data, using both inductive and deductive coding methods.

Results: South African businesses use a combination of financial and non-financial project selection criteria across four main goals and benefit categories: customer experience, operational efficiency, business culture, and traditional project evaluation. The fifth proposed goal (new business models) was not used to evaluate DT projects. The most influential technologies that drive the selection of DT projects were data-related, such as data storage, data processing, machine learning, and data-driven decision-making.

Conclusion: Companies in South Africa can use traditional project evaluation criteria together with several new criteria to determine the value of DT projects more holistically. This study also suggests several key practical takeaways for businesses that are aspiring to implement their own DT projects.

Keywords: digital transformation; project selection criteria; project evaluation criteria; fourth industrial revolution; project portfolio management.

\section{Introduction}

Digital transformation (DT) is a radical change in the way that business is performed (Wessel et al. 2021:44) through the use and integration of advanced digital technologies (Matt, Benlian \& Hess 2015:339) to enable new business models, improve operational efficiency, and enhance customer experiences (Berman 2012:19; Henriette, Feki \& Boughzala 2015:440; Morakanyane, Grace \& O'Reilly 2017:433). Digital transformation projects use new technologies to radically change the ways of working in an organisation to improve efficiency, reduce waste, manage data and information better, support better decision-making, and implement the DT of a business. Henriette et al. (2015:432) discuss how simple technological innovation on its own (such as the use of smartphones, advanced analytics, and additive manufacturing) is best described as simple digitisation rather than as DT.

Digital transformation projects differ significantly from traditional information technology (IT) projects. Ebert and Duarte (2018:1) note that 'DT is about adopting disruptive technologies'. Parviainen et al. (2017:65) describe how digitalisation is causing disruptive changes to the operating environment of businesses. Lee et al. (2018:6) state that the introduction of these technologies is a form of disruptive innovation (and even go on to claim that DT should be classified as 'super-disruptive'), as they are intended to address the needs of new markets with completely different needs from those of established markets. Wessel et al. (2021:3) promote this idea that a project to implement DT is different from a typical project or an IT organisational 
transformation. Digital transformation projects redefine a company's value proposition, aim to change an organisation's identity, and drive a new business strategy. This differs from a traditional IT project that aims to support and enable the existing strategy and identity. This shows that DT is significantly disruptive. Projects to implement DT are therefore significantly different from traditional projects. There are some key differences between traditional and DT projects, as noted by several different authors (Table 1).

Kutnjak, Pihiri and Furjan (2019:1295) show some examples of DT projects: the manufacturing industry performs DT projects to improve their business processes, reduce their expenses, and integrate their technologies to remain competitive on the global scale. Their DTs focus on the adoption of fourth industrial revolution technologies to become integrated smart factories (such as digital printing, 3D production, and the Internet of Things). The retail industry has focused their DTs on the adoption of e-commerce platforms and improvement of sales, which they have achieved through improved digital communication and the adoption of new ways of working (lean, agile, flexible work arrangements). Healthcare has also leveraged DT projects, such as video consultations with patients, digitalisation of medical records and the introduction of e-health platforms. This has helped them to reduce their costs and improve the quality of care and has allowed for the adoption of telemedicine.

Keskin (2019:66) highlights that DT projects have high levels of uncertainty and high interdependence relationships, which make the 'project portfolio selection decision considerably complicated'. Rodrigues et al. (2019:291) suggest that research should be performed to understand the specific aspects of DT projects that could be included in decision-making models for project portfolios. Henriette et al. (2015:440) state that information about the realisation of

TABLE 1: Differences between traditional projects and digital transformation.

\begin{tabular}{|c|c|c|c|}
\hline \multirow{2}{*}{$\begin{array}{l}\text { Variable } \\
\text { Effect on the } \\
\text { company value } \\
\text { proposition }\end{array}$} & \multirow{2}{*}{$\begin{array}{l}\text { Traditional project } \\
\begin{array}{l}\text { Enable current value } \\
\text { proposition }\end{array}\end{array}$} & \multicolumn{2}{|c|}{$\begin{array}{l}\text { Digital transformation Reference } \\
\text { project }\end{array}$} \\
\hline & & $\begin{array}{l}\text { Redefine value } \\
\text { proposition }\end{array}$ & $\begin{array}{l}\text { Wessel et al. } \\
(2021: 8)\end{array}$ \\
\hline $\begin{array}{l}\text { Effect on the } \\
\text { company's identity }\end{array}$ & $\begin{array}{l}\text { Support current } \\
\text { identity }\end{array}$ & $\begin{array}{l}\text { (Possibly) change the } \\
\text { company's identity }\end{array}$ & $\begin{array}{l}\text { Wessel et al. } \\
(2021: 8)\end{array}$ \\
\hline $\begin{array}{l}\text { Relationship to } \\
\text { business strategy }\end{array}$ & $\begin{array}{l}\text { Driven by business } \\
\text { strategy }\end{array}$ & $\begin{array}{l}\text { Driver of business } \\
\text { strategy }\end{array}$ & $\begin{array}{l}\text { Yoo, Henfridsson } \\
\text { and Lyytinen } \\
\text { (2010:733) }\end{array}$ \\
\hline Drivers & $\begin{array}{l}\text { Incremental } \\
\text { performance } \\
\text { improvements, } \\
\text { a changing } \\
\text { cyber-security } \\
\text { environment }\end{array}$ & $\begin{array}{l}\text { Market trends, } \\
\text { technological changes, } \\
\text { paradigm shifts }\end{array}$ & $\begin{array}{l}\text { Horlach, Drews and } \\
\text { Schirmer } \\
\text { (2016:1421) }\end{array}$ \\
\hline \multirow[t]{3}{*}{ Focus } & $\begin{array}{l}\text { Security, reliability, } \\
\text { predictability }\end{array}$ & Innovation, disruption & $\begin{array}{l}\text { Horlach et al. } \\
\text { (2016:1421) }\end{array}$ \\
\hline & $\begin{array}{l}\text { Exploit existing } \\
\text { knowledge, update } \\
\text { legacy systems }\end{array}$ & $\begin{array}{l}\text { Agility, speed of } \\
\text { delivery, solving new } \\
\text { problems }\end{array}$ & Gartner (2019) \\
\hline & $\begin{array}{l}\text { Enhance existing } \\
\text { capabilities }\end{array}$ & $\begin{array}{l}\text { Develop new } \\
\text { capabilities }\end{array}$ & $\begin{array}{l}\text { Henriette et al. } \\
(2015: 437)\end{array}$ \\
\hline Platforms & $\begin{array}{l}\text { Runs on established } \\
\text { infrastructure }\end{array}$ & $\begin{array}{l}\text { Experiments with new } \\
\text { infrastructure }\end{array}$ & $\begin{array}{l}\text { Horlach et al. } \\
(2016: 1421)\end{array}$ \\
\hline Mode of execution & $\begin{array}{l}\text { Traditional, } \\
\text { sequential, waterfall } \\
\text { methodology }\end{array}$ & $\begin{array}{l}\text { Exploratory, } \\
\text { non-linear, agile }\end{array}$ & Gartner (2019) \\
\hline
\end{tabular}

value from executing DT projects is lacking in the literature. Even in standard projects, managing a portfolio of projects is a complex exercise, and the measurement of a project's value is a key management tool to aid the project selection process. Thus, this study adds to the literature by asking the question 'How to measure the value of a DT project?' in order to enable effective project portfolio selection.

This study specifically investigates DT projects in South Africa, as it is a unique and interesting context for DT. Ndemo and Weiss (2017:329) show that there is considerable adoption of digital technologies on the African continent. However, Van Dyk and Van Belle (2019:519) and Mubako (2017) suggest that there is a lack of information on the perceptions and use cases of DT in South Africa, as it is a fairly new phenomenon and there is limited literature in this context. De Wet (2001) discusses South Africa as a 'technology colony', where a reliance on overseas technologies and low local technology transfer drives a different strategic agenda to that experienced in 'First World' countries. It is thus necessary to evaluate whether 'overseas' literature applies equally well in the South African context.

\section{Research objectives}

This research attempts to support management in considering multiple measures of value so that resources and capital spend can be appropriately allocated between traditional and DT projects. As DT projects are disruptive to an organisation (Lee et al. 2018:6) and are significantly different from traditional IT projects (Wessel et al. 2021:8), it is important to understand the value that DT projects will bring to an organisation before they are implemented and make substantial changes to the business.

The study was exploratory, and aimed to determine whether traditional criteria were sufficient to describe the full value of DT projects by asking three key research questions:

- RQ1: What are the core goals and objectives of digital transformation strategies in South African businesses?

- RQ2: What selection criteria and measures of value do South African businesses use for digital transformation project portfolio management?

- RQ3: Which technologies are the strongest drivers of digital transformation in South Africa?

Interviews with managers and leaders within South African businesses were used to gather data and to draw conclusions, in order to capture nuances that could easily be missed in quantitative methods. The outcome of this research should help to guide managers in South Africa to execute sustainable DT strategies - particularly to improve their project portfolio selection methodologies.

\section{Literature review Dimensions of digital transformation}

Berman (2012:19) states that DT can be achieved across three dimensions: improving the customer experience, enhancing existing operations, and developing new business models 
(through a combination of the first two dimensions). Berghaus and Back (2016:4) discuss business culture as an additional dimension of DT. Henriette et al. (2015:440) build on this model by discussing the digital capabilities that are pursued by organisations within these dimensions.

Companies have found it increasingly important to maintain and improve their customer relationships (Kohli \& Johnson 2011:155). The rise of globalisation, the internet, and e-commerce adds a considerable amount of viable competition into the market. However, as technology improves, it also introduces new opportunities to capture markets that were previously out of reach. As such, the customer experience has become a key differentiator (Sebastian et al. 2017:199) and is one of the main targets for DT. Digitalisation can radically transform the customer's experience through:

- creating omnichannel communications (Newman 2019)

- improving the offerings to ensure that experiences and products are adapted to the requirements of the customers (Lawson 2019)

- improving customer relationships through improved communication (which leads to increased trust) (Westerman, Bonnet \& McAfee 2014:2).

Digital transformation also allows for more efficient operations, systems, and processes to be put in place. Here, new technologies help to create more efficient environments and workplaces, which in turn support the key goals of companies. This creates improved margins for the company in many ways, including:

- reduced costs through the reduction of waste and the automation of tasks (Sackschewsky et al. 2019)

- increased revenue through increased operating capacity (Miers 2017)

- radical improvements to the productivity of individuals, business processes, and internal communications (Sackschewsky et al. 2019).

Digital transformation can also lead to the adoption of new business models. A business model is the structure of elements that a company uses to deliver value to its customers. Osterwalder et al. (2011) describe nine dimensions of business models in the well-known 'business model canvas'. Henriette et al. (2015:438) argue that the core goals of business model transformation centre on extending the existing market, improving the customer value propositions, or changing the business model in reaction to changes in the industry. Kotarba (2018:126) reviews the major changes in business models over several 'waves' of innovation, such as the transition from analogue to digital resources, or the introduction of usergenerated resources such as the public data posted on social media. Other examples are revenue models, which have seen a shift from traditional sales and subscriptions to new models such as software-as-a-service and 'freemium' (where advertisements are placed within the product for revenue).

Berghaus and Back (2016:4) discuss culture and expertise as explicit dimensions of their digital maturity model, highlighting the need for a company culture that embraces digital technologies and is less risk-averse to DT projects. Several other authors briefly mention the importance of employees as enablers of DT; for example:

- Henriette et al. (2015:437) discuss how these changes affect the way that people work, comment on the new skills required to enable DT, and mention the impact that human resources have on an organisation, and how it needs to evolve with transformation.

- Morakanyane et al. (2017:436) discuss the requirement to improve employee productivity and to allow for shifts in company culture.

- Matt et al. (2015:342) highlight the need for improved cooperation between people as a key enabler of DT.

- Westerman et al. (2014:3) show that DT provides opportunities to unlock value by allowing employees to refocus their efforts on more strategic tasks.

Digital technologies can improve the environment for employees in terms of improved decision-making through access to data and insight (Bose 2009:155), improved safety through advanced cyber-physical systems (Romero et al. 2016:5), and vastly improved use of human capital through skills development and reduced work inequality (Atiku 2019).

However, DT projects do not live in isolation. An organisation needs to divide its resources between traditional projects and DT projects, and this is achieved through the execution of project portfolio management.

\section{Project portfolio management}

According to the Project Management Institute (2021:244), a portfolio is 'projects, programs, subsidiary portfolios, and operations managed as a group to achieve strategic objectives', and 'portfolio management is defined as the centralised management of one or more portfolios to achieve strategic objectives'. Project portfolio management (PPM) is thus a complex set of activities, and one of the key activities in PPM is selecting and prioritising projects.

Cooper (1990:1) set the standard for portfolio management with the introduction of the 'stage-gate' model. His model describes a project process consisting of several key and value-adding steps, with gates at the end of each stage that check that the project has achieved its sub-goals before moving on to further stages. This not only ensures proper governance and that project reviews are performed, but also acts to filter out projects that no longer seem promising. Ideas are initially filtered out according to their proposed value from the business cases, and then subsequently measured to ensure that their value remains achievable. This can be seen in the updated model of Cooper (2014:21) (Figure 1).

There is a small but growing body of literature that describes the management of DT project portfolios. Keskin (2019:66) notes that the high level of uncertainty of Industry 4.0 projects makes it difficult for decision-makers to evaluate projects precisely'. Their solution is to consider decision- 


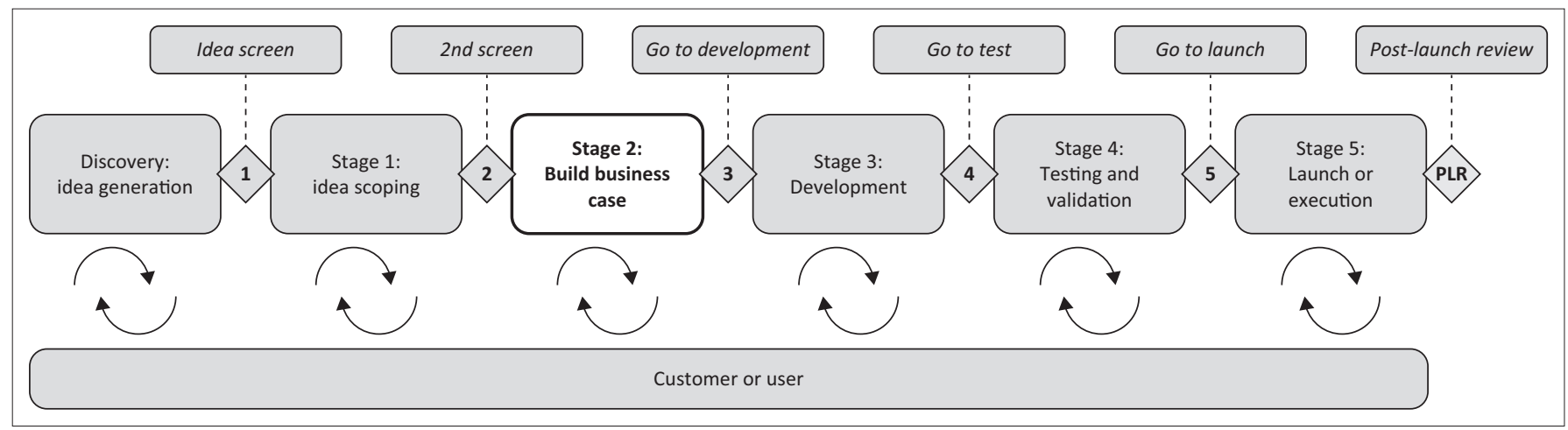

Source: Adapted from Cooper, R.G., 2014, 'What's next? After stage-gate', Research-Technology Management 57(1), 20-31. https://doi.org/10.5437/08956308X5606963 FIGURE 1: Idea-to-launch stage-gate model.

making under 'fuzzy' conditions. Fuzzy logic is an approach that is popular with decision-makers and academics (Berghaus \& Back 2017:5; Chatterjee, Hossain \& Kar 2018:482; Rodrigues et al. 2019:286).

\section{Project selection criteria}

One of the most important processes in PPM is the analysis and selection of the most valuable projects from a pool of project proposals. There are many methods for selecting projects in a portfolio (see Kornfeld and Kara, 2011, for a review of various techniques). However, those techniques still rely on a set of clearly defined selection criteria, along with ways of measuring those criteria. This study focuses on the development of those selection criteria in the context of DT projects.

Levine (2005:254) notes that, for most projects, the key indicators of project value are determined through financial criteria, such as return on investment (ROI) or net present value (NPV). However, Cooper, Edgett and Kleinschmidt (1999:347) and Killen, Hunt and Kleinschmidt (2008:52) state that financial methods and criteria are insufficient to prioritise projects fully. Chatterjee et al. (2018:480) performed an analytical hierarchy process to prioritise a project portfolio according to various project selection criteria (Table 2).

However, Barthel, Stark and Hess (2020:4) show that it is still unclear how PPM is implemented for DT projects. Their research investigated companies that created new departments specifically to handle the complex multi-project environments for DT. Very little literature currently exists on selection criteria that are specific to DT. Rodrigues et al. (2019:290) conducted a useful review of the prioritisation techniques but did not provide insight into the specific criteria used in their models. Isikli et al. (2018:97) developed a model for the optimisation of DT project portfolios. Their linear programming solution made use of the generic criteria of investment cost, energysaving parameters, labour-saving parameters, material-saving parameters, and inter-dependencies of projects. However, this presents only a single set of criteria, and does not provide insight into how these specific criteria were chosen.

In summary, the literature reveals that there are some gaps in the knowledge of how to manage DT project portfolios.
Morakanyane et al. (2017:439) state that more research is required to understand how digital technologies and capabilities are used to create value in organisations. Berghaus and Back (2016:13) show that latecomer industries are prone to experimentation with DT, but do not embrace a scientific or systematic approach to DT until much later. This highlights a lack of overall maturity for DT in the industry, which can be attributed to a knowledge gap in how to manage DT projects.

Thus, there is a gap in the literature for the identification of project selection criteria that are specific to the management of DT project portfolios. This study aims to fill that gap.

\section{Conceptual model}

The conceptual model (Figure 2) is a representation of selection criteria for DT projects. The selection criteria are assessed during the business case development (stage 2 in Cooper, 2014, p. 21) and are broken down into two layers: goals or benefit categories, and project selection criteria.

The goals and benefit categories are derived from various strategic dimensions proposed by different authors:

- Berman (2012:19) and Henriette et al. (2015:440): Improved operating efficiency, improved customer experience, and new business models

- Berghaus and Back (2016:4): Business culture

- Jiang and Klein (1999:65): Traditional project evaluation criteria

RQ1 aims to investigate the extent to which the proposed goals or benefit categories are used by South African businesses for DT projects.

Within each of the five goals and benefit categories, various authors suggest selection criteria to consider when selecting a project. There is extensive literature on the numerous possible selection criteria to consider, and so the conceptual model cannot be comprehensive; instead, it exists as a framework that represents just one possible set of these criteria.

RQ2 aims to determine the specific sets of project selection criteria used by South African businesses for DT projects. 
TABLE 2: Examples of project evaluation criteria.

\begin{tabular}{|c|c|c|c|}
\hline Criteria & Sub-criteria & Criteria & Sub-criteria \\
\hline \multirow{6}{*}{$\begin{array}{l}\text { Commercial } \\
\text { matters }\end{array}$} & Project budget & \multirow[t]{6}{*}{ Project risk } & Fund arrival rate \\
\hline & $\begin{array}{l}\text { Expected return on } \\
\text { investment }\end{array}$ & & Technical risk \\
\hline & Payback period & & Completion time \\
\hline & Potential market share & & Financial risk \\
\hline & Ethics & & Quality risk \\
\hline & Initial cash outlay & & Legal exposure \\
\hline \multirow[t]{7}{*}{$\begin{array}{l}\text { Project } \\
\text { owners }\end{array}$} & $\begin{array}{l}\text { Availability of } \\
\text { workforce }\end{array}$ & \multirow{4}{*}{$\begin{array}{l}\text { Internal } \\
\text { operating } \\
\text { issues }\end{array}$} & Employee skills and experience \\
\hline & Management attitude & & Workforce changes \\
\hline & Strategic fit & & Environment changes \\
\hline & Owner's policies & & Operations changes \\
\hline & Patent protection & \multirow{3}{*}{$\begin{array}{l}\text { Project bid } \\
\text { competition }\end{array}$} & Number of competitors \\
\hline & Reputation & & Competitor strategy \\
\hline & & & $\begin{array}{l}\text { Ability to provide } \\
\text { comprehensive control } \\
\text { information }\end{array}$ \\
\hline
\end{tabular}

Source: Adapted from Chatterjee, K., Hossain, S.A. \& Kar, S., 2018, 'Prioritization of project proposals in portfolio management using fuzzy AHP', Opsearch 55(2), 478-501. https://doi. org/10.1007/s12597-018-0331-3

Metrics and calculation methods are then used to measure the specific values of each of the selection criteria (e.g. cost-focused criteria are broken down into specific metrics such as ROI, NPV, and internal rate of return). This level of detail is beyond the scope of this study.

\section{Research methodology}

This applied research is an exploratory study to test certain notions presented in literature. A qualitative approach was chosen for this study. This is justified by the exploratory nature of the research, in which the outcomes are an understanding of the status quo in the local context, and the results populate specifics into the conceptual framework. Here, interviews (as opposed to quantitative methods) were selected to ensure that a deeper understanding of the phenomena was captured. Henriette et al. (2015:436) show that the majority of literature on DT utilised case studies as the methodology, 'due to the contemporaneity of the subject'.

Semi-structured interviews were chosen as the research instrument. This is supported by Rowley (2012:260), who argues that interviews are best suited to gaining insight into processes, experiences, behaviours, and attitudes. This is especially useful when it is possible to identify certain people in critical positions who have a large amount of information on the topic being researched.

For the interviews, participants were purposively selected to be in senior or executive management positions of large companies with significant operations in South Africa. All the interviewed businesses are performing, or have performed, DT to some degree. This lends some credibility to the results. The companies were not explicitly screened for their involvement in DT, but some potential respondents might have declined owing to their lack of active DT. Potential interviewees were invited through several platforms, including direct email, LinkedIn messaging, and direct invitations through a professional network.
The 11 interviewees were diverse in respect to industry, experience, company size, and digital maturity (Table 3). All the interviewees worked for local companies (or multinational companies with significant local divisions), and each interviewee's portfolio was mainly focused on Southern African or South African markets. The sample consisted of all qualifying candidates who responded positively within the time constraints of the research.

The interviews were conducted virtually for 1 hour each, with 15 possible questions prepared. The interview recordings were transcribed by artificial intelligence (AI) systems (Otter.ai) and edited by hand to create intelligent transcriptions. These were analysed within a CAQDAS system using descriptive coding and alternating between inductive and deductive approaches through three cycles. The resultant codes were then grouped into thematic clusters by the researcher.

\section{Ethical considerations}

Ethical clearance was obtained from the ethics committee of the Faculty of Engineering, Built and Information Technology, University of Pretoria (EBIT/74/2020).

More information can be obtained at https:/ /www.up.ac.za/ faculty-of-engineering-built-environment-it/article/15815/ faculty-committee-for-research-ethics-integrity

\section{Results and discussion}

\section{RQ1 What are the core goals and objectives of digital transformation strategies in South African businesses? and RQ2: What selection criteria and measures of value do South African businesses use for digital transformation project portfolio management?}

The interviewees were asked to discuss their DT strategies and the specific goals that they set. The goals that were discussed fitted into the five goals and benefit categories of the conceptual model. The sections below discuss some of the key findings and a comprehensive tally of selection criteria can be found in Appendix A.

\section{Operational efficiency}

The most broadly discussed criteria for operational efficiency were financial, such as cost reductions and increased revenue. Financial criteria were discussed by all 11 interviewees. This is not surprising, as DT projects still need to appeal to a business strategy, and any business strategy focuses on the bottom line. It also shows that South African companies place significant emphasis on finances when making their project portfolio decisions. However, several authors, including Voss and Kock (2013:848) and Cooper and Edgett (2003:48), have found that financial criteria alone are insufficient to ensure project portfolio success. The interviewees tended to agree, as can be seen by the diversity of the other criteria. 
Goals and benefits of DT

RQ1: What are the core goals and objectives of digital transformation strategies in South African businesses?

\section{Selection criteria for DT projects}

RQ2: What selection criteria and measures of value do South African businesses use for digital transformation project portfolio management?
Metrics and methods

Beyond the research scope

\begin{tabular}{|l|l|l|}
\hline \multirow{2}{*}{$\begin{array}{l}\text { Berman (2012) and } \\
\text { Henriette et al. (2015) }\end{array}$} & $\begin{array}{l}\text { Reduced costs } \\
\text { Improved productivity }\end{array}$ & Miers (2017) \\
\hline $\begin{array}{lll}\text { Increased revenue } \\
\text { Integration of systems }\end{array}$ & Lee et al. (2018) \\
\hline $\begin{array}{l}\text { Greater process flexibility } \\
\text { Reduced product cycle time }\end{array}$ & Dossi and Patelli (2010) \\
\hline $\begin{array}{l}\text { Improved supplier relationships } \\
\text { Improved knowledge management }\end{array}$ & Henriette et al. (2015) \\
\hline
\end{tabular}

\begin{tabular}{|c|c|c|}
\hline \multirow{3}{*}{ Customer experience } & Omni-channel alignment & Newman (2019) \\
\hline & $\begin{array}{l}\text { Improved customer relations } \\
\text { Improved product offering }\end{array}$ & Westerman et al. (2014) \\
\hline & $\begin{array}{l}\text { Attracting new customers } \\
\text { Customer satisfaction }\end{array}$ & Dossi and Patelli (2010) \\
\hline $\begin{array}{l}\text { Berman (2012) and } \\
\text { Henriette et al. (2015) }\end{array}$ & $\begin{array}{l}\text { User maturity } \\
\text { Improved collaboration and interaction }\end{array}$ & Henriette et al. (2015) \\
\hline
\end{tabular}

\begin{tabular}{|l|l|l|}
\hline New business models & $\begin{array}{l}\text { Adopting elements of "2nd Wave" across: } \\
\text { Client segments and relationships } \\
\text { Value proposition and resources } \\
\text { Channels and partnerships } \\
\text { Activities and energy usage } \\
\text { Financials }\end{array}$ & Kotarba (2018) \\
\cline { 2 - 3 } $\begin{array}{l}\text { Berman (2012) and } \\
\text { Henriette et al. (2015) }\end{array}$ & $\begin{array}{l}\text { Extension of market } \\
\text { Reshape customer value proposition }\end{array}$ & Henriette et al. (2015) \\
\hline
\end{tabular}

\begin{tabular}{|l|l|l|}
\hline Business culture & $\begin{array}{l}\text { Improved morale and attitude } \\
\text { Reduced employee turnover }\end{array}$ & van Dyk and van belle (2019) \\
\hline $\begin{array}{lll}\text { Internal communication network } \\
\text { Development of relevant skills } \\
\text { Improved decision-making }\end{array}$ & Bose (2009) \\
\hline Improved safety & Romero et al. (2016) \\
\hline $\begin{array}{l}\text { Self-learning opportunities } \\
\text { Increased demographic inclusion and project } \\
\text { team diversity }\end{array}$ & $\begin{array}{l}\text { Buengeler, Leroy and De } \\
\text { stobbeleir (2018) }\end{array}$ \\
\hline
\end{tabular}

\begin{tabular}{|c|c|c|}
\hline \multirow{3}{*}{ Project evaluation criteria } & Time- and cost-focused criteria & Tukel and room (2001) \\
\hline & Technical performance and functionality & $\begin{array}{l}\text { International Institute of } \\
\text { Business Analysis (2015) }\end{array}$ \\
\hline & $\begin{array}{l}\text { Organisational and internal needs } \\
\text { Strategic factors } \\
\text { Various project risks } \\
\text { Management support }\end{array}$ & Chatterjee et al. (2018) \\
\hline
\end{tabular}

i


TABLE 3: Attributes of interviewees.

\begin{tabular}{|c|c|c|c|c|c|}
\hline Inter-viewee & Industry & No. of employees & $\begin{array}{l}\text { Strategic technological } \\
\text { positioning }\end{array}$ & Interviewee position & Direct experience (years) \\
\hline A & Management consulting & 2000 & Local leader & C-Suite executive $\dagger$ & 8 \\
\hline B & Strategy consulting & 420 & Global leader & C-Suite executive $\dagger$ & 2 \\
\hline C & Banking & 30000 & Global leader & Senior manager & 5 \\
\hline D & Banking & 30000 & Global leader & Head of department & 6 \\
\hline E & Banking & 10000 & Mature follower & Head of department & 6 \\
\hline $\mathrm{F}$ & Market research & 6 & Local leader & Managing director & 20 \\
\hline G & Petro-chemicals & 33000 & Fast follower & C-Suite executive $\dagger$ & 10 \\
\hline $\mathrm{H}$ & Insurance & 15000 & Local leader & C-Suite executive $\dagger$ & 10 \\
\hline । & Food and beverage & 20000 & Unknown & C-Suite executive $\dagger$ & 4 \\
\hline J & $\mathrm{ICT}$ & 5000 & Global leader & Head of department & 10 \\
\hline $\mathrm{K}$ & Professional services & 430000 & Global leader & Head of department & 6 \\
\hline
\end{tabular}

$\dagger, \mathrm{C}$-Suite executive refers to executive leadership in a company, such as CEO, CTO, CFO, et cetera.

technologies or professional consultants offering suggestions. However, in some cases, the driver for capabilities was to reach aspirational goals: 'How can we use technology to push the boundaries as far as we can?' (B).

Interviewees also discussed production criteria, such as production rates (A; B; E; F; G; H; J; K), turnaround time (E; F; H; I; J; K), production efficiency (A; C; E; F; G; H; J; K), scalability (B; F; G; H; J), and capacity (B; J; K). These criteria were discussed through the lens of how digital solutions could improve the current operations: 'Embrace machine learning, AI, ... robotic process automation, to improve your own operations in terms of efficiencies' (J). This again highlighted the need for DT projects to enable improvements that ultimately support the business strategy.

\section{Customer experience}

The two most important groups of selection criteria are the improvement of the customer relationship (B; C; D; E; H; J; K) and the measurement of customer activity $(A ; C ; D ; J)$. There were seven distinct measures for customer relationships, including understanding customer needs and customer behaviour. The relationship with the customer is a focus area for DT projects because new technologies create new opportunities to interact with the customer. The improved collection of data allows companies to build more realistic customer profiles and thus understand customer needs more closely:

[There are] new ways of thinking about how to deal with customers, new ways of understanding the value that you can extract from applying digital processes and procedures, ... new ways of understanding customer behaviours, (D).

In turn, this enables companies to create products with features more relevant to the customer (sometimes with hyper-personalisation of the products).

Customer activity is a group of selection criteria that measure the details of the interactions between the customer and the company. These include more traditional criteria (additional sales, new customers), and digital-specific criteria (digital migration and platform adoption, profitability per customer). By understanding how the customer engages with the business, the company is better able to optimise those interactions, which leads to a stronger customer relationship. Many of these interactions are being pushed onto digital platforms (e.g. mobile apps, e-commerce sites), and so DT projects play a critical role in changing the mode of engagement for businesses: 'A big [customer] experience disruptor has been the advent of digital [because] by being relevant and close to the point of decision-making, you are more likely to get the customer's business' (K).

The interviewees were also invested in customer experience and satisfaction. Improved customer feedback (in respect of the quantity and quality of feedback) $(\mathrm{F} ; \mathrm{H} ; \mathrm{J})$ and improved net promoter score $(\mathrm{G} ; \mathrm{J})$ were mentioned as lagging criteria for the DT projects, as they could only be measured once the DT project had been implemented. Interviewees also mentioned leading measures of customer experience, such as reduction of non-value-adding processes $(\mathrm{B} ; \mathrm{C} ; \mathrm{D} ; \mathrm{E}$; J), ease of doing business $(\mathrm{H} ; \mathrm{J} ; \mathrm{K})$, and reduced waiting times $(\mathrm{C} ; \mathrm{E})$.

\section{Adoption of new business models}

The discussions on new business models by the interviewees were brief. 'The business model starts changing the fundamentals of the industry ... and is accelerated through the introduction of certain digitisation and digitalisation trends that we see' (A). In terms of the business model canvas by Osterwalder et al. (2011), interviewees only commented on a handful of elements. Some of the activities would change to match the shift in key resources as digital technologies were adopted. Three interviewees $(\mathrm{C} ; \mathrm{J} ; \mathrm{K})$ mentioned that they aimed to shift the value proposition to be more inclusive of personalised products and pricing, also mentioned by (Lawson 2019), but the interviewees did not go into any detail. Customer relationships were also discussed in detail, as mentioned in the previous paragraph, as were the adoption of online and omnichannel experiences mentioned by Newman (2019). Interviewees mentioned that two goals were to retain existing customers $(\mathrm{A} ; \mathrm{C} ; \mathrm{F} ; \mathrm{H} ; \mathrm{K})$ and to capture new customers (E), but the only proposed changes were the shift from physical storefronts to more streamlined digital services (e.g. through apps), and incremental cost savings through the adoption of more efficient technologies. Similarly, regarding the revenue structure, two interviewees 
(D; K) discussed new revenue streams (including cross-sell and upselling opportunities) but did not seem to value those ideas highly. It is worth noting that this section made up less than $5 \%$ of the interview data in each interview, and so it is unwise to draw generalised conclusions.

\section{Business culture}

Around half of the interviewees (B; C; E; G; H) did not mention the business culture aspects as part of their initial conceptualisation of DT. The other half (A; D; F; I J J K) found it to be a critical component when considering DT projects, in line with the arguments made by Hartl and Hess (2017) and Rowles and Brown (2017).

The first group of criteria focused on digital skills, with six interviewees (A; F; H; I; J; K) discussing it. Some interviewees (A; B; G; I; J; K) discussed how the automation of work offered new opportunities for employees to be relieved of tedious, mundane work so that they could focus on insight generation and decision-making (tasks that the interviewees were reluctant to automate completely). These interviewees also described how technologies are not yet capable of fully replacing humans (even in automation solutions), and so it is important to make sure that the employees can handle the changes that come with DT. 'Look at your learning space to make sure that you're upskilling individuals to be able to manage the space going forward' (G). This aligns with Chaka (2020:373), who outlined the digital nature of many critical skills that are required for the fourth industrial revolution.

The second group of criteria focused on the impact of DT on a company's structure, stating that, without a drive for reskilling, many employees could lose their jobs. 'You either reskill people to return to somewhere in the organisation or you start cutting jobs' (I). The depth of discussion on this dimension is noteworthy and may be attributed to the high levels of local unemployment and the drive to protect the workforce. However, this contradicts the conclusions reached by Parschau and Hauge (2020:129), who suggested that the adoption of digital technologies in South Africa has either a negligible or a positive impact on employment.

\section{Project execution criteria}

The interviewees briefly mentioned the project execution principles that are broadly discussed in the literature (Chatterjee et al. 2018:485; Iamratanakul, Shankar \& Dimmitt 2009:287; Jiang and Klein 1999:65). These included project risks (A; G), ROI (A; B; C; K), project costs (A; B; C; D; F; H; $\mathrm{K})$, and strategic alignment elements $(\mathrm{A} ; \mathrm{C} ; \mathrm{G} ; \mathrm{H} ; \mathrm{J} ; \mathrm{K})$. However, the interviewees did not consider these as unique to DT and referred to their traditional project processes to determine these values. Thus, there is little evidence to include project execution in the final model. Further research will be required to determine if these concepts need to be considered at a strategic level.

Changes to decision-making was the most discussed criterion in this group. This is owing to the link between decision- making and data technologies, such as machine learning and $\mathrm{AI}$ (which is discussed in more detail in the next section). The criteria included the timing and accessibility of data, as well as the quality of the insights drawn.

\section{Summary of answers to RQ1 \& RQ2}

The results from the interviews showed that the core goals and objectives of DT projects in South African businesses are the improvement of operational efficiency, of customer experience, and of business culture. The implementation of new business models is a secondary objective. Traditional project evaluation criteria are also considered but tend to be less focused on for DT projects.

The selection criteria used by South African companies are a combination of traditional ones (revenue, new customers, strategic alignment), along with some DT-specific criteria used (digital migration of customers, upskilling, digital capability development). While the companies are making adaptations and changes to the processes that are used, these changes typically do not affect the structure of the portfolio management process.

\section{RQ3 - Which technologies are the strongest drivers of digital transformation in South Africa?}

With this more exploratory research question, the study tried to discover which technologies had the greatest impact on local DT. This was measured by the frequency and relative importance that each interviewee placed on different technologies. While this method does not generalise to all companies in the local context, it provides an interesting snapshot of the technologies that provide most value in the current business environment. The full results are captured in Appendix B.

The most important technological shift for the interviewees has been the use of data. 'A key thing for me is data, ... because what digital does is it allows you to have access to a plethora of data' (K). This includes all stages in the data lifecycle, from new data sources (digital sensors, social media), to storage (cloud migration, data lakes), to processing (data science, predictions, and the Internet of Things), to advanced machine learning (chatbots, machine learning, AI), and finally to data-driven decision-making. The interviewees spent a considerable amount of time highlighting the role that data has played in their transformation. 'The ability to access any company data at any time on a live platform is transformative for business strategy' $(F)$. This rise in data and computing power is foundational for other radical technologies, such as predictive maintenance and process automation. However, the interviewees made special mention of the value of the integration of data and the integration of systems. Data has existed for many years, but the new uses and integrations of data provide the stepchange that enables DT.

The interviewees also mentioned some other technologies. Digital platforms (cloud storage, videoconferencing, and 
mobile applications) were discussed by many interviewees as enablers of new ways of working and as improved channels for communicating with and understanding of customers. 'Most companies now recognise that they are actually a digital or a technology platform company' $(\mathrm{H})$. Some other technologies (specific to each business) were also briefly mentioned but were not the core focuses of the digital strategy. One interviewee stated that 'in South Africa, digital is so much more difficult than in first-world countries [sic] and countries a little more comfortable with technology', showing that the adoption of all digital technologies in South Africa is a challenging task.

Thus, there is substantial evidence that certain technologies have a greater impact on DT in South Africa, and that the most influential technologies are:

- Data - data science, machine learning, and AI

- Digital platforms - cloud, videoconferencing, mobile applications

This outcome has not been explored in any depth in the literature.

\section{Conclusions and recommendations}

This study aimed to explore the selection criteria and measures of value used by South African businesses for portfolio management of DT projects. A qualitative approach was conducted through interviews with senior leaders of prominent businesses, in order to gain deeper understanding of the selection criteria. The diversity of the interviewees (in terms of industry, business size, and professional experience) enabled robust conclusions to be drawn.

The results of this study align with the existing literature (Berghaus \& Back 2016; Berman 2012; Henriette et al. 2015) about the alignment of the dimensions of DT with the goals and benefits of DT, which are improving operating efficiency, customer experience, business models, and business culture. These results extend the literature through the development of a goals and benefits framework for DT projects, with new detail of the selection criteria and measures of value that are used for each dimension, in the South African context.

The interviewees noted that technologies that supported better use of data (data science, machine learning, and AI) were the primary drivers of their DTs, but that technologies that supported digital platforms also made a substantial contribution to the change.

In summary, South African companies use both traditional selection criteria (revenue, new customers, strategic alignment), along with some DT-specific selection criteria (digital migration of customers, upskilling, digital capability development) to measure the value of DT. When DT is still new to the organisation, the processes and selection criteria for measuring value are unclear, and thus extraordinary measures must be taken to pursue the project (justification through strategy alone, additional time to execute projects, measurement of value through benchmarks, etc.). However, as the company continues its DT journey, the unique aspects of the process become increasingly integrated into the standard processes.

Practically, there are several key takeaways for businesses:

1. A company does not need a new or different PPM system to begin engaging with DT. Organisations can use the existing processes but allow the selection of DT projects some flexibility in dealing with the unique and complex aspects.

2. Digital transformation goals typically fall into one of three key areas: improving operational efficiency, enhancing partner or customer relationships, and developing new business models. However, to execute these goals successfully, the strategy should also account for the empowerment of its employees (through cultural change, upskilling, and creating buy-in).

3. In South African businesses, the use of data is the leading technological driver of DT, followed by the adoption of digital platforms.

\section{Future work}

An unexpected outcome of the study has been the appearance of various stages of maturity in the PPM processes for DT. While this study does not cover the phenomena in significant depth, it does open a new avenue of study to determine the prevalence of PPM maturity in a DT context.

This research was performed during the COVID-19 crisis in 2020, when participants and companies were subject to a national lockdown. This significantly disrupted business through the restricted movement of people, disruptions to supply chains and business operations, and threats to employee health and safety. The magnitude of this disruption's effect on the research is unclear. There would be value in studying the relationship between this crisis and DT in respect of changes to attitudes, drivers of DT, and the resilience of companies that did (or did not) engage in DT before the crisis.

\section{Acknowledgements Competing interests}

The authors have declared that no competing interest exists.

\section{Authors' contributions}

All the authors contributed to the development and writing of the article. W.M.G. conducted the research as part of his master's dissertation under the supervision of E.v.d.L. and H.S.

\section{Funding information}

This research received no specific grant from any funding agency in the public, commercial, or not-for-profit sectors. 


\section{Data availability}

Raw data were generated at the University of Pretoria. Derived data supporting the findings of this study are available from the corresponding author on request.

\section{Disclaimer}

The views and opinions expressed in this article are those of the authors and do not necessarily reflect the official policy or position of any affiliated agency of the authors.

\section{References}

Atiku, S.O., 2019, Human capital formation for the fourth industrial revolution, IG Global, Hershey PA.

Barthel, P., Stark, N. \& Hess, T., 2020, Exploring new areas for project portfolio management: Evolving practices for digital transformation projects, 28th European Conference on Information Systems, Marrakesh, 15-17 June 2020.

Berghaus, S. \& Back, A., 2016, 'Stages in digital business transformation: Results of an empirical maturity study', Mediterranean Conference on Information Systems, empirical maturity study', Mediter

Berghaus, S. \& Back, A., 2017, 'Disentangling the fuzzy front end of digital transformation: Activities and approaches', 38th International Conference on Information Systems, Seoul, 10-13 December 2017

Berman, S.J., 2012, 'Digital transformation: Opportunities to create new business models', Strategy \& Leadership 40(2), 16-24. https://doi.org/10.1108/1087857 1211209314

Bose, R., 2009, 'Advanced analytics: Opportunities and challenges', Industria Management \& Data Systems 109(2), 155-172. https://doi.org/10.1108/026355 70910930073

Braun, M. \& Schweidel, D.A., 2011, 'Modeling customer lifetimes with multiple causes of churn', Marketing Science 30(5), 881-902. https://doi.org/10.1287/mksc. 1110.0665

Chaka, C., 2020, 'Skills, competencies and literacies attributed to $4 \mathrm{IR} /$ Industry 4.0 Scoping review', IFLA Journal 46(4), 369-399. https://doi.org/10.1177/034 0035219896376

Chatterjee, K., Hossain, S.A. \& Kar, S., 2018, 'Prioritization of project proposals in portfolio management using fuzzy AHP', Opsearch 55(2), 478-501. https://doi. org/10.1007/s12597-018-0331-3

Cooper, R.G., 1990, 'Stage-gate systems: A new tool for managing new products', Business Horizons 33(3), 44-54. https://doi.org/10.1016/0007-6813(90)90040-I

Cooper, R.G., 2014, 'What's next? After stage-gate', Research-Technology Management 57(1), 20-31. https://doi.org/10.5437/08956308X5606963

Cooper, R.G. \& Edgett, S.J., 2003, 'Overcoming the crunch in resources for new product development', Research-Technology Management 46(3), 48-58. https:// doi.org/10.1080/08956308.2003.11671566

Cooper, R.G., Edgett, S.J. \& Kleinschmidt, E.J., 1999, 'New product portfolio management: Practices and performance', The Journal of Product Innovation Management 16(4), 333-351. https://doi.org/10.1111/1540-5885.1640333

De Wet, G., 2001, Emerging from the technology colony: A view from the South, Graduate School of Technology Management, University of Pretoria, Pretoria, South Africa

Dossi, A. \& Patelli, L., 2010, 'You learn from what you measure: Financial and nonfinancial performance measures in multinational companies', Long Range Planning 43(4), 498-526. https://doi.org/10.1016/j.Irp.2010.01.002

Ebert, C. \& Duarte, C.H.C., 2018, 'Digital transformation', IEEE Software 35(4), 16-21. https://doi.org/10.1109/MS.2018.2801537

Gartner, 2019, Gartner Glossary: Bimodal, Gartner, viewed 16 March 2020, from https://www.gartner.com/en/information-technology/glossary/bimodal.

Gori, E., 1996, 'Portfolio selection of capital investment projects in the Durban Metropolitan Region', Construction Management \& Economics 14(5), 451-456. https://doi.org/10.1080/014461996373313

Hartl, E., \& Hess, T., 2017, 'The role of cultural values for digital transformation: Insights from a Delphi study', 23rd Americas Conference on Information Systems, Boston, 10-12 August 2017.

Henriette, E., Feki, M. \& Boughzala, I., 2015, 'The shape of digital transformation: A systematic literature review', Ninth Mediterranean Conference on Information Systems (MCIS), Samos, 3rd-5th October 2015.

Horlach, B., Drews, P. \& Schirmer, I., 2016, Bimodal IT: Business-IT in the age of digital transformation', MKWI 2016 - Strategisches IT-Management, Ilmenau, 09-11 March 2016.

lamratanakul, S., Shankar, R. \& Dimmitt, N.J., 2009, 'Improving project portfolio management with strategic alignment', PICMET '09 - 2009 Portland International Conference on Management of Engineering \& Technology, Portland, OR, 02-06 August 2009.

Isikli, E., Yanik, S., Cevikcan, E. \& Ustundag, A., 2018. 'Project Portfolio selection for the digital transformation era', in A. Ustundag \& E. Cevikcan (eds.), Industry 4.0 Managing the digital transformation, pp 93-105, Springer Series in Advanced Manufacturing, Springer, Cham.
Jeong, K.Y. \& Phillips, D.T., 2001, 'Operational efficiency and effectiveness measurement', International Journal of Operations \& Production Management 21(11), 1404-1416. https://doi.org/10.1108/EUM0000000006223

Jiang, J.J. \& Klein, G., 1999, 'Project selection criteria by strategic orientation', Information \& Management 36(2), 63-75. https://doi.org/10.1016/S03787206(99)00009-9

Keskin, F.D., 2019, 'A two-stage fuzzy approach for Industry 4.0 project portfolio selection within criteria and project interdependencies context', Journal of MultCriteria Decision Analysis 27(1-2), 65-83. https://doi.org/10.1002/mcda.1691

Killen, C.P., Hunt, R.A. \& Kleinschmidt, E.J., 2008, 'Project portfolio management for product innovation', International Journal of Quality \& Reliability Management 25(1), 24-38. https://doi.org/10.1108/02656710810843559

Kohli, R. \& Johnson, S., 2011, 'Digital transformation in latecomer industries: $\mathrm{ClO}$ and CEO leadership lessons from Encana Oil \& Gas (USA) Inc', MIS Quarterly Executive 10(4), 141-156.

Kornfeld, B.J. \& Kara, S., 2011, 'Project portfolio selection in continuous improvement', International Journal of Operations \& Production Management 31(10), International Journal of Operations \& Production Nan
1071-1088. https://doi.org/10.1108/01443571111172435

Kotarba, M., 2018, 'Digital transformation of business models', Foundations of Management 10(1), 123-142. https://doi.org/10.2478/fman-2018-0011

Kutnjak, A., Pihiri, I. \& Furjan, M.T., 2019, 'Digital transformation case studies across industries - Literature review', 2019 42nd International Convention on Information and Communication Technology, Electronics and Microelectronics (MIPRO), Opatija, pp. 1293-1298, 20-24 May 2019.

Lawson, K., 2019, What is digital transformation and why does it matter?, viewed 10 January 2019, from https://www.bloomreach.com/en/blog/2019/05/digitaltransformation.html.

Lee, M., Yun, J., Pyka, A., Won, D., Kodama, F., Schiuma, G. et al., 2018, 'How to respond to the Fourth Industrial Revolution, or the Second Information Technology Revolution? Dynamic new combinations between technology, market, and society through open innovation', Journal of Open Innovation: Technology, Market, and Complexity 4(21), 1-24. https://doi.org/10.3390/joitmc4030021

Levine, H.A., 2005, Project portfolio management: A practical guide to selecting projects, managing portfolios, and maximizing benefits, John Wiley \& Sons, San Francisco, CA.

Matt, C., Benlian, A. \& Hess, T., 2015, 'Digital transformation strategies', Business Information Systems 57(5), 339-345. https://doi.org/10.1007/s12599-0150401-5

Miers, D., 2017, How to shape digital transformation for operational efficiency, viewed 18 June 2020, from https://www.brighttalk.com/webcast/14435/260891/ how-to-shape-digital-transformation-for-operational-efficiency.

Morakanyane, R., Grace, A.A. \& O'Reilly, P., 2017, 'Conceptualising digital transformation in business organisations: A systematic review of literature', 30th BLED eConference 2017, Slovenia, 18-21 June 2017

Mubako, A., 2017, Digital transformation. The realignment of information technology and business strategies for retailers in South Africa, Anchor Academic Publishing, Hamburg.

Ndemo, B. \& Weiss, T., 2017, 'Making sense of Africa's emerging digital transformation and its many futures', Africa Journal of Management 3(3-4), 328-347. https://doi. org/10.1080/23322373.2017.1400260

Newman, D., 2019, 5 digital transformation trends: Reshaping customer experience for 2019, viewed 22 June 2020, from https://www.forbes.com/sites/ danielnewman/2019/02/28/5-digital-transformation-trends-reshapingdanielnewman $/ 2019 / 02 / 28 / 5$-digital-transform

Osterwalder, A., Pigneur, Y., Oliveira, M.A.-Y. \& Ferreira, J.J.P., 2011, 'Business model generation: A handbook for visionaries, game changers and challengers', African Journal of Business Management 5(7), 22-30.

Parschau, C. \& Hauge, J., 2020, 'Is automation stealing manufacturing jobs? Evidence from South Africa's apparel industry', Geoforum 115, 120-131. https://doi. org/10.1016/j.geoforum.2020.07.002

Parviainen, P., Kääriäinen, J., Tihinen, M. \& Teppola, S., 2017, 'Tackling the digitalisation challenge: How to benefit from digitalisation in practice', International Journal of Information Systems and Project Management 5(1), 63-77.

Project Management Institute, 2021, 1.2.3.3 Portfolio management. Guide to the project management body of knowledge $\left(\right.$ PMBOK $^{\circledR}$ guide), 6th edn., Project Management Institute Inc., Newtown Square, PA.

Rodrigues, C.M., Deschamps, F., Loures, E.F.R., Cestari, J.M.A.P. \& De Freitas, I.H., 2019, 'Digital transformation project portfolio selection/prioritization: Literature 2019, 'Digital transformation project portfolio selection/prioritization. Literature Engineering and Operations Management, Novi Sad, 15-17 July 2019.

Romero, D., Stahre, J., Wuest, T., Noran, O., Bernus, P., Fast-Berglund, Å. et al., 2016, 'Towards an Operator 4.0 typology: A human-centric perspective on the fourth industrial revolution technologies', International Conference on Computers and Industrial Engineering (CIE46) Proceedings, Tianjin, 29-31 October 2016

Rowles, D. \& Brown, T., 2017, Building digital culture: A practical guide to successful digital transformation, Kogan Page Publishers, London.

Rowley, J., 2012, 'Conducting research interviews', Management Research Review 35(3/4), 260-271. https://doi.org/10.1108/01409171211210154

Rui, Z., Li, C., Peng, F., Ling, K., Chen, G., Zhou, X. et al., 2017, 'Development of industry performance metrics for offshore oil and gas project', Journal of Natural Gas Science and Engineering 39(March), 44-53. https://doi.org/10.1016/j.jngse. 2017.01.022

Rutaganda, L., Bergstrom, R., Jayashekhar, A., Jayasinghe, D. \& Ahmed, J., 2017, 'Avoiding pitfalls and unlocking real business value with RPA', Journal of Financial Transformation 46(11), 104-115. 
Sackschewsky, C., Cohron, M., Giammarco, S. \& Tiernan, K., 2019, Achieving operational efficiency through digital transformation, BDO USA, Delaware.

Sandberg, J., Mathiassen, L. \& Napier, N., 2014, 'Digital options theory for IT capability investment', Journal of the Association for Information Systems 15(7), 422-453. https://doi.org/10.17705/1jais.00365

Sebastian, I.M., Mocker, M., Ross, J.W., Moloney, K.G., Beath, C. \& Fonstad, N.O., 2017 'How big old companies navigate digital transformation', MIS Quarterly 16(3), 197-213.

Shamma, H.M., 2012, 'Toward a comprehensive understanding of corporate reputation: Concept, measurement and implications', International Journal of Business and Management 7(16), 151-169. https://doi.org/10.5539/ijbm. v7n16p151

Tukel, O.I. \& Rom, W.O., 2001, 'An empirical investigation of project evaluation criteria', International Journal of Operations \& Production Management 21(3), 400-416. https://doi.org/10.1108/01443570110364704
Van Dyk, R. \& Van Belle, J.-P., 2019, 'Factors influencing the intended adoption of digital transformation: A South African case study', Federated Conference on Computer Science and Information systems, Leipzig, 01-04 September 2019.

Voss, M. \& Kock, A., 2013, 'Impact of relationship value on project portfolio success nvestigating the moderating effects of portfolio characteristics and externa turbulence', International Journal of Project Management 31(6), 847-861. https://doi.org/10.1016/j.ijproman.2012.11.005

Wessel, L., Baiyere, A., Ologeanu-Taddei, R., Cha, J. \& Jensen, T., 2021, 'Unpacking the difference between digital transformation and IT-enabled organizational transformation', Journal of Association of Information Systems 22(1), 102-129. https://doi.org/10.17705/1jais.00655.

Westerman, G., Bonnet, D. \& McAfee, A., 2014, 'The nine elements of digital transformation', MIT Sloan Management Review 55(3), 1-6.

Yoo, Y., Henfridsson, O. \& Lyytinen, K., 2010, 'The new organising logic of digital innovation: An agenda for information systems research', Information Systems Research 21(4), 724-735. https://doi.org/10.1287/isre.1100.0322 


\section{Appendix A}

Table A-1: Project selection criteria from interviewees.

\begin{tabular}{|c|c|c|}
\hline Group & Project selection criteria & Frequency \\
\hline \multicolumn{3}{|l|}{ Operational efficiency } \\
\hline $\begin{array}{l}\text { Processing cycle time } \\
\text { Dossi and Patelli (2010) }\end{array}$ & $\begin{array}{l}\text { *Turnaround time } \\
\text { Processing time reduction } \\
\text { Speed of project execution } \\
\text { Velocity (Agile) } \\
\text { Time saved }\end{array}$ & $\begin{array}{l}5 \\
2 \\
1 \\
1 \\
1\end{array}$ \\
\hline $\begin{array}{l}\text { Costs } \\
\text { Sackschewsky et al. (2019) }\end{array}$ & $\begin{array}{l}\text { *Cost reduction or cost saving } \\
\text { Net costs }\end{array}$ & $\begin{array}{l}8 \\
5\end{array}$ \\
\hline $\begin{array}{l}\text { Revenue } \\
\text { Miers (2017) }\end{array}$ & $\begin{array}{l}\text { *Revenue increase } \\
\text { New revenue streams } \\
\text { Price \& pricing } \\
\text { Increased sales volumes }\end{array}$ & $\begin{array}{l}7 \\
2 \\
2 \\
1\end{array}$ \\
\hline $\begin{array}{l}\text { Efficiency and productivity } \\
\text { Sackschewsky et al. (2019) }\end{array}$ & $\begin{array}{l}\text { *Level of optimisation or efficiency } \\
\text { Utilisation } \\
\text { Value-add per person } \\
\text { Throughput } \\
\text { Yields }\end{array}$ & $\begin{array}{l}7 \\
5 \\
2 \\
1 \\
1\end{array}$ \\
\hline $\begin{array}{l}\text { Integration of systems } \\
\text { Lee et al. (2018) }\end{array}$ & $\begin{array}{l}\text { Spatial integration and interoperability } \\
\text { Ability to integrate with existing IT }\end{array}$ & $\begin{array}{l}1 \\
1\end{array}$ \\
\hline $\begin{array}{l}\text { Production } \\
\text { Tukel and Rom (2001) }\end{array}$ & $\begin{array}{l}\text { *Production rates } \\
\text { *Production efficiency } \\
\text { *Scale } \\
\text { *Capacity } \\
\text { Developer throughput (Agility) }\end{array}$ & $\begin{array}{l}5 \\
4 \\
3 \\
3 \\
1\end{array}$ \\
\hline $\begin{array}{l}\text { Maintenance } \\
\text { Jeong and Phillips (2001) }\end{array}$ & $\begin{array}{l}\text { Maintenance costs } \\
\text { Downtime }\end{array}$ & $\begin{array}{l}3 \\
1\end{array}$ \\
\hline Predictability & $\begin{array}{l}\text { Variability } \\
\text { Reliability and predictability } \\
\text { Service-level achievement }\end{array}$ & $\begin{array}{l}2 \\
2 \\
1\end{array}$ \\
\hline $\begin{array}{l}\text { Automation } \\
\text { Rutaganda et al. (2017) }\end{array}$ & $\begin{array}{l}\text { Number of processes automated } \\
\text { Human hours automated }\end{array}$ & $\begin{array}{l}2 \\
1\end{array}$ \\
\hline Quality & Quality of production & 3 \\
\hline $\begin{array}{l}\text { Capability } \\
\text { Berghaus and Back (2016) }\end{array}$ & $\begin{array}{l}\text { *Improvement of existing capability } \\
\text { *New capabilities added } \\
\text { Spending on research and development } \\
\text { Number of patents }\end{array}$ & $\begin{array}{l}6 \\
5 \\
4 \\
1\end{array}$ \\
\hline \multicolumn{3}{|l|}{ Customer experience } \\
\hline $\begin{array}{l}\text { Customer relations and } \\
\text { improved product offering } \\
\text { Westerman et al. (2014) }\end{array}$ & $\begin{array}{l}\text { *Understanding customer needs } \\
\text { *Understanding customer behaviour or } \\
\text { profile } \\
\text { Value customer gets from doing business } \\
\text { with the organisation } \\
\text { *Product features } \\
\text { *Product relevance to customer } \\
\text { Benefits to customer } \\
\text { Product personalisation }\end{array}$ & $\begin{array}{l}6 \\
4 \\
3 \\
3 \\
2 \\
2 \\
2\end{array}$ \\
\hline $\begin{array}{l}\text { Customer activity } \\
\text { Dossi and Patelli (2010) }\end{array}$ & $\begin{array}{l}\text { *Digital migration or platform adoption } \\
\text { *Additional sales } \\
\text { *Active platform users } \\
\text { *Profitability per customer } \\
\text { New customers }\end{array}$ & $\begin{array}{l}8 \\
7 \\
3 \\
3 \\
1\end{array}$ \\
\hline $\begin{array}{l}\text { Customer experience and } \\
\text { satisfaction } \\
\text { Dossi and Patelli (2010) } \\
\text { Henriette et al. (2015) }\end{array}$ & $\begin{array}{l}\text { *Waiting time } \\
\text { *Customer feedback } \\
\text { Level of customer support } \\
\text { Order processing time } \\
\text { *Ease of doing business } \\
\text { *Reduction of non-value-adding } \\
\text { processes } \\
{ }^{*} \text { Net promoter score } \\
\text { Self-service capabilities } \\
\text { Adherence to service level agreements }\end{array}$ & $\begin{array}{l}6 \\
6 \\
5 \\
4 \\
3 \\
3 \\
2 \\
1 \\
1\end{array}$ \\
\hline $\begin{array}{l}\text { Retention of customers } \\
\text { Braun and Schweidel (2011) }\end{array}$ & $\begin{array}{l}\text { Reduced attrition of customer base } \\
\text { Return business from the same customer } \\
\text { Lifetime value of customer }\end{array}$ & $\begin{array}{l}5 \\
5 \\
3\end{array}$ \\
\hline $\begin{array}{l}\text { Reputation } \\
\text { Shamma (2012) }\end{array}$ & $\begin{array}{l}\text { Customer feedback } \\
\text { Awareness of organisation and products } \\
\text { Company or product differentiation }\end{array}$ & $\begin{array}{l}6 \\
2 \\
2\end{array}$ \\
\hline \multicolumn{3}{|l|}{ Business culture } \\
\hline $\begin{array}{l}\text { Skills } \\
\text { Berman (2012) }\end{array}$ & $\begin{array}{l}\text { *Skills development/upskilling } \\
\text { Flexible work }\end{array}$ & $\begin{array}{l}5 \\
4\end{array}$ \\
\hline $\begin{array}{l}\text { Workforce structure } \\
\text { Gori (1996) }\end{array}$ & $\begin{array}{l}\text { *People impact } \\
\text { *Job losses or creation }\end{array}$ & $\begin{array}{l}4 \\
3\end{array}$ \\
\hline $\begin{array}{l}\text { Diversity } \\
\text { Atiku (2019) }\end{array}$ & Workforce diversity & 1 \\
\hline $\begin{array}{l}\text { Employee satisfaction } \\
\text { Van Dyk and Van Belle (2019) }\end{array}$ & $\begin{array}{l}\text { Employee experience (of the company) } \\
\text { Employee attrition }\end{array}$ & $\begin{array}{l}1 \\
1\end{array}$ \\
\hline
\end{tabular}

Table A-1 (Continues...): Project selection criteria from interviewees.

\begin{tabular}{llc}
\hline Group & Project selection criteria & Frequency \\
\hline Project execution & & \\
Costs and financial indicators & *Project costs & 4 \\
Jiang and Klein (1999) & *Return on investment & 3 \\
& Profitability & 3 \\
& Weighted average cost of capital (WACC) & 1 \\
& and hurdle rate & \\
Legal and regulatory & *Risk & 6 \\
Rui et al. (2017) & Compliance & 3 \\
& Health and safety & 1 \\
Decision-making & *Timing of data & 8 \\
Bose (2009) & *Access to data & 7 \\
& *Quality of insights & 4 \\
Strategic alignment & *Growth and market share & 5 \\
lamratanakul et al. (2009) & *Other strategic alignments & 4 \\
& Environmental impact & 2 \\
Project meta-criteria & Perceived value & 1 \\
Chatterjee et al. (2018) & *Project risk & 2 \\
& Project schedule & 3 \\
& Project dependencies & 2 \\
\hline
\end{tabular}

Note: Elements with * are referred to in the results section. 


\section{Appendix B}

Table B-1: Digital technologies.

\begin{tabular}{|c|c|c|c|c|c|c|c|c|c|c|c|c|c|}
\hline Group & Sub-group & Frequency & A & B & C & D & E & $\mathbf{F}$ & G & H & 1 & J & $\mathbf{K}$ \\
\hline Data & Machine learning and artificial intelligence & 5 & $x$ & $x$ & & & & & & & $x$ & $x$ & $\mathrm{x}$ \\
\hline Data & Real-time insights & 5 & & $x$ & & & & $x$ & & & $\mathrm{x}$ & $x$ & $\mathrm{x}$ \\
\hline Data & Business intelligence & 5 & & $\mathrm{x}$ & $x$ & & & & $x$ & & & $x$ & $\mathrm{x}$ \\
\hline Data & Simulation & 4 & & $\mathrm{x}$ & & & $\mathrm{x}$ & $\mathrm{x}$ & $\mathrm{x}$ & & & & \\
\hline Data & Digital sensors and the Internet of Things & 3 & $\mathrm{x}$ & $\mathrm{x}$ & & & & & & & & $\mathrm{x}$ & \\
\hline Data & Predictive maintenance & 3 & $x$ & $x$ & & & & & & & & $x$ & \\
\hline Data & Chatbots & 2 & & & & & & $\mathrm{x}$ & & & & $\mathrm{x}$ & \\
\hline Data & Data management and governance & 2 & & $\mathrm{x}$ & & & & & & & & & $\mathrm{x}$ \\
\hline Data & Other and nondescript & 4 & & $\mathrm{x}$ & & $\mathrm{x}$ & & & & & & $\mathrm{x}$ & $\mathrm{x}$ \\
\hline Platforms & Cloud storage & 6 & $\mathrm{x}$ & $\mathrm{x}$ & & & & & & $\mathrm{x}$ & $\mathrm{x}$ & $\mathrm{x}$ & $\mathrm{x}$ \\
\hline Platforms & Cloud services & 4 & & $x$ & $x$ & & & & & & $x$ & $\mathrm{x}$ & \\
\hline Platforms & Platform integrations & 2 & $\mathrm{x}$ & & & & $x$ & & & & & & \\
\hline Platforms & Customer relationship management & 2 & & $\mathrm{x}$ & & & & & & & & $\mathrm{x}$ & \\
\hline Platforms & Collaboration tools & 1 & $x$ & & & & & & & & & & \\
\hline Platforms & Other and nondescript & 5 & & & & $\mathrm{x}$ & $x$ & $x$ & & $\mathrm{x}$ & & & $\mathrm{x}$ \\
\hline Legacy systems & $\begin{array}{l}\text { Information and communication technology and } \\
\text { internet }\end{array}$ & 5 & $\mathrm{x}$ & $\mathrm{x}$ & & & & $\mathrm{x}$ & & & $\mathrm{x}$ & $\mathrm{x}$ & \\
\hline Legacy systems & Voice-only telecoms & 1 & & & & & & & & & & $x$ & \\
\hline Legacy systems & USSD & 1 & & & & $x$ & & & & & & & \\
\hline Other & Automation and RPA & 5 & $\mathrm{x}$ & $x$ & & & & & & & $x$ & $x$ & $\mathrm{x}$ \\
\hline Other & Fintech & 1 & & & & & & & & & & $\mathrm{x}$ & \\
\hline Other & Smart grids & 1 & $\mathrm{x}$ & & & & & & & & & & \\
\hline
\end{tabular}

Note: An ' $\mathrm{X}$ ' denotes that the interviewee included the particular technology in one of their responses during the interview. There is no consideration for the quantity or quality of the comments made for each technology. 